\title{
Community-level management of bio-resources for augmenting income from coconut-based farming systems in Kerala state, India
}

\author{
S. Kalavathi*, Jeena Mathew, S. Indhuja, Merin Babu and K. Muralidharan ${ }^{1}$ \\ ICAR-Central Plantation Crops Research Institute, Regional Station, Kayamkulam-690 533, Kerala, India \\ ${ }^{1}$ ICAR-Central Plantation Crops Research Institute, Kasaragod-671 124, Kerala, India
}

(Manuscript Received: 08-06-2020, Revised: 30-08-2020, Accepted:24-09-2020)

\begin{abstract}
On-farm management of farm residues for mass multiplication of beneficial microbes plays an important role in organic farming as well as integrated nutrient management by improving soil health. Community-level production of organic inputs from crop residues can be a potential source of income for farmers' groups also. A large scale operational research on community-based bio-resource management, along with soil test based nutrient management, was undertaken by ICAR-CPCRI with financial support from NABARD in the major organic tract of Kerala in the coastal belt - Kanjikuzhy block during 2014-2016. The bio-resource management components under technology integration included farm-level production of organics from crop residues, enrichment using bio-agents, utilization of enriched organics for soil and plant health management and production of bio-primed planting materials. For enhancing the efficiency of Trichoderma-enriched organic manure, two ideal media viz., coir pith compost + neem cake (4:1) and coir pith compost + neem cake + poultry manure + cow dung (2:1:1:1) were standardized. Coconut seedlings produced through bio-priming with Trichoderma sp. showed early germination (90\%), higher recovery percentage (79.5\%), higher collar girth (17 cm), more number of fronds (9) and height $(160 \mathrm{~cm})$. Farm-based participatory action management integrating cost-effective bio-resource management interventions in coconut-based farming systems resulted in improvements in income from coconut by 26 per cent and intercrops by 142.9 per cent, contributing to an increase in the average farm income by 149.8 per cent. The average knowledge index of the respondents related to bio-resource management increased by 115.8 per cent and that of integrated nutrient management by 74.5 per cent.
\end{abstract}

Keywords: Bio-resource management, coconut-based farming systems, community approaches, income augmentation

\section{Introduction}

The economic well-being of a farmer depends not only on the quantity of food produced but also on the effective product and by-product utilization as well as the importance assigned to on-farm integration and waste utilisation (Reddy and SangArun, 2011). Use of farm waste for mass multiplication of beneficial microbes is one of the important tools for sustainable crop production. Onfarm management of agricultural wastes not only improves the soil health but reduce the dependency of farmers on external inputs and thereby increases the profit. Specific management practices associated with sustainable agriculture include more incorporation of "natural" processes such as nutrient cycling, nitrogen fixation, and pest-predator relationships; reduction in off-farm inputs with greatest potential environmental risks; greater reliance on the biological and genetic potential of plants and animals; improved matching of farming activities with resource limitations; and improved management and conservation of soil, water, energy, and biological resources (National Research Council, 1989). Community-level production of organic inputs from crop residues can be a potential source of income for farmers' groups also. The availability of waste biomass from a well-managed

*Corresponding Author: kalacpcri@gmail.com 
coconut garden with 175 trees $\mathrm{ha}^{-1}$ has been estimated as 14 tonnes $\mathrm{ha}^{-1}$ year $^{-1}$ in the form of leaves, spathe, bunch waste, and husk (Subramanian et al., 2005). Homesteads with diverse intercrops ensure additional crop wastes for organic recycling. Available biomass from coconut gardens can be utilized as mulch or converted to composts by employing earthworms or microbial cultures; ICARCPCRI has standardized appropriate agrotechniques in this regard (Thomas et al., 2010). However, these technologies were not fully exploited by the farming communities on a larger scale, but have greater relevance as more and more farmers are shifting from chemical farming to organic farming in many parts of the country. For instance, the Government of Kerala is promoting organic farming throughout the coastal region of the state where coconut is the principal crop and is grown more or less organically. To enhance the adoption of bio-resource management technologies in coconut farming developed by ICAR-CPCRI, a large scale operational research programme was implemented in one of the coastal blocks of Kerala viz., Kanjikuzhi, during 2014-2016. The specific objective of the project was to train the framers on biomass recycling, enriching with beneficial microbes coupled with soil moisture conservation techniques and crop diversification and enable community-level production to enhance the productivity and income from the coconut-based farming system. Impact of the programme is reported in this paper.

\section{Materials and methods}

The locale of the study was Kanjikuzhy block panchayat that belongs to Alappuzha district in Kerala state, India. The soil of the tract is sandy, characterized by low organic matter content and poor water holding capacity resulting in low productivity. The region receives more than 2700 $\mathrm{mm}$ total rainfall from both South-West and NorthEast monsoons.

Bio-resources management practices, involving production and utilization of bio-agent enriched organics out of crop residues to supplement the soil test-based nutrient requirements for improving the soil and plant health, were demonstrated in 52 holdings. Selection of farmers was made in consultation with the nine registered Coconut Producers Federations (CPFs) of 8 to 10 community-based organizations, each having 40 to 100 coconut farmers in a contiguous area.

Native strains of Trichoderma were isolated from Kanjikuzhy area and evaluated for antagonistic activity against pathogens causing leaf rot and stem bleeding diseases of coconut. A community-level production unit of beneficial microbes was established to facilitate decentralized production of formulations of beneficial microbes and enriched organics. Locally available organic substrates and their combinations were evaluated for mass multiplication of bio-agent in terms of multiplication rates and impact on plant growth and yield. One model nursery was then established for the production of coconut seedlings that are bio-primed with the bio-agent mentioned above.

Awareness creation and capacity building programmes were conducted for the participating farmers. Extension personnel and people's representatives in Local Self Governments were also involved in this programme to achieve effective horizontal dissemination of the demonstrated technologies.

Baseline data on knowledge and adoption of bio-resource management and integrated nutrient management practices along with socio-economic profile was collected in an interview schedule. The knowledge and adoption levels were measured on a three-point continuum viz., proper, partial, and no knowledge/adoption with scores 2, 1 and 0 , respectively. These scores were converted to an index as a percentage to maximum obtainable score on a specific practice.

Quantitative data on inputs and output were recorded by the participating farmers in a booklet provided with them. The post-project data were compared with baseline data for assessing the impact.

\section{Results and discussion}

\section{Profile of selected farmers}

The average age of the farmers was 60 with the majority $(67 \%)$ in the category of $50-70$ years. The vast majority (94\%) had educational levels above high school level with 65 per cent members 
in high school/higher secondary level of education. Nearly 85 per cent of them were found to be fulltime farmers having more than 15 years of experience in farming with their major occupation as farming from the beginning $(46 \%)$ or after retirement (38\%). In general, the farmers of the area were found to have higher mass media utilization (73 to $90 \%$ ), social participation ( 72 to $76 \%$ ) and extension orientation (50 to 74 ) even before starting the project as the majority of them were office bearers of different coconut producer federations, which were further enhanced through participation in project activities.

\section{Capacity development}

Selected farmers were rigorously trained on composting techniques, microbial enrichment of organics and soil test based nutrient application with special emphasis to bio-resource management and imparted a large number of skill development programmes (Table 1), based on which the farmers could adopt site-specific management practices and further replicate to farmers of the entire block area.

A total number of 84 programmes including awareness programmes, training-cum-demonstrations, small group discussions, farmer field schools and household level trainings were conducted with 806 beneficiaries.

\section{Interventions on bio-resource management}

\section{Isolation of native strains of Trichoderma from Kanjikuzhy block}

As part of bio-resource management activities, isolated eight native strains of Trichoderma from Kanjikuzhy block panchayat area and Trichoderma isolate KKT-6 showed highest antagonistic activity to leaf rot and stem bleeding pathogens of coconut under in vitro conditions. Field studies against leaf rot disease also revealed effective control.

\section{Evaluation of locally available substrates/ substrate mixes for mass multiplication of Trichoderma sp.}

Based on the field evaluation of locally available organic substrates for enrichment with Trichoderma sp., standardized two ideal organic substrate combinations - coir pith compost + neem cake $(4: 1)$ and coir pith compost + neem cake + poultry manure + cow dung $(2: 1: 1: 1)$.

\section{Production and utilization of Trichoderma - enriched organic manure and Trichoderma cake}

The master farmers/farmer groups/ organic manure production unit produced $41 \mathrm{MT}$ of enriched organics using various substrate combinations involving coir pith compost, cow dung, neem cake

Table1. Details of capacity development programmes conducted

\begin{tabular}{|c|c|c|c|}
\hline $\begin{array}{l}\text { Sl. } \\
\text { No. }\end{array}$ & Programme & $\begin{array}{c}\text { No. of } \\
\text { batches }\end{array}$ & $\begin{array}{c}\text { No. of } \\
\text { beneficiaries }\end{array}$ \\
\hline 1. & Awareness programmes on bio-resource management & 2 & 102 \\
\hline 2. & $\begin{array}{l}\text { Training-cum-demonstrations: Production and mass multiplication of bio-agents, } \\
\text { microbial enrichment of organics }\end{array}$ & 9 & 85 \\
\hline 3. & $\begin{array}{l}\text { Training-cum-demonstrations: Composting techniques - coir pith ( } 3 \text { methods), } \\
\text { vermicompost, EM composting }\end{array}$ & 5 & 100 \\
\hline 4. & Training -cum-demonstrations: Preparation of Trichoderma cake & 2 & 51 \\
\hline 5. & $\begin{array}{l}\text { Training on soil test based nutrient application, bio-resource management } \\
\text { and intercropping (9) }\end{array}$ & 9 & 133 \\
\hline 6. & FFS on IPM of Rhinoceros beetle and Red palm weevil (8) & 8 & 164 \\
\hline 7. & Field day-cum-exchange of planting materials (1) & 1 & 42 \\
\hline \multirow[t]{5}{*}{8.} & Small group/household level training-cum-demonstrations: & & \\
\hline & a. Plant protection & 13 & 94 \\
\hline & b. Microbial enrichment of organics & 21 & 21 \\
\hline & c. Treatment of manure pits with Metarhizium & 14 & 14 \\
\hline & Total & 84 & 806 \\
\hline
\end{tabular}


and poultry manure. The organic manure production unit also produced 3500 Trichoderma cakes for using against coconut leaf rot disease. The groups could generate an income of ₹ 2,17,250 through the sale of products.

\section{Establishment of bio-primed coconut nursery}

Bio-priming was undertaken in a nursery established with 200 seed nuts -150 Chowghat Green Dwarf (CGD) and 50 Chowghat Orange Dwarf (COD). First, bio-priming was done with Trichoderma-enriched neem cake in seedbeds @ $250 \mathrm{~g}$ per seed nut along with pouring of 1 litre of Trichoderma solution@20 g L $\mathrm{g}^{-1}$ around the nut at the time of sowing. Second, third and fourth bio-primings were done during $3^{\text {rd }}, 5^{\text {th }}$ and $7^{\text {th }}$ months respectively with Trichoderma@50 g per seed nut. The growth parameters recorded are provided in Table 2.

Table 2. Growth parameters of bio-primed coconut seedlings

\begin{tabular}{lrrc}
\hline Parameters & CGD & COD & Average \\
\hline No. of leaves** & 8.7 & 8.4 & 8.6 \\
Collar girth (cm)** & 17.0 & 16.1 & 16.8 \\
Height (cm)** & 162.7 & 153.6 & 160.3 \\
Germination (\%)* & 89.3 & 90.0 & 89.5 \\
Recovery of quality seedlings (\%) & $7 * .3$ & 80.0 & 79.5 \\
\hline
\end{tabular}

* Observation on $90^{\text {th }}$ day; ${ }^{* *}$ Observations during $11^{\text {th }}$ month

The farmer groups produced 159 good quality bio-primed coconut seedlings having average collar girth of $17 \mathrm{~cm}$, nine fronds and $160 \mathrm{~cm}$ height during $11^{\text {th }}$ month. The majority $(89.5 \%)$ of the nuts germinated within 90 days and recovery of good quality seedlings was to the tune of 79.5 per cent. In a study by El-Mohamedy and Abd-El-Baky (2008), bio-priming of T. harzianum with co-application of P. fluorescens and B. subtilis was found to be significantly reducing the incidence of root rot pathogenic disease caused by $F$. solani and $R$. solani in pea under greenhouse and field conditions. Seed bio-priming with drought-tolerant isolates of $T$. harzianum enhanced drought tolerance in wheat as drought-induced changes like stomatal conductance, net photosynthesis and chlorophyll fluorescence were delayed (Shukla et al., 2014). It was also demonstrated that $T$. harzianum induced defense responses and systemic resistance in addition to the control of plant pathogens (Alfano et al., 2007).

\section{Soil test-based nutrient management}

Soil health cards based on test results were provided to the farmers, based on which they have applied recommended quantities of organics, green manure and fertilizers. Cowpea seeds@100 gwere sown in coconut basins and incorporated during the onset of flowering for nutrient addition and soil health. Mulching for coconut and intercrops using crop residues and husk was undertaken for soil moisture conservation and enhanced microbial growth.

During the pre-intervention period, it was observed that the soil was deficient in $\mathrm{K}, \mathrm{Mg}$ and $\mathrm{B}$ (Table. 3), which can be related to the practice of over liming and the resultant nutrient antagonism

Table 3. Comparison of soil fertility parameters before and after project interventions

\begin{tabular}{llrrrr}
\hline Sl. & Parameter & \multicolumn{2}{c}{ Soil fertility status } & \multicolumn{2}{c}{ Leaf nutrient status } \\
\cline { 3 - 5 } No. & & $\mathbf{2 0 1 4}$ & $\mathbf{2 0 1 6}$ & $\mathbf{2 0 1 4}$ & $\mathbf{2 0 1 6}$ \\
\hline 1. & $\mathrm{pH}$ & 6.66 & 6.55 & - & - \\
2. & $\mathrm{OC}(\%)$ & 0.72 & 0.69 & 0.13 & 0.21 \\
3. & $\mathrm{P}(\mathrm{ppm})$ & 269.58 & 1.48 & 1.73 \\
4. & $\mathrm{K}(\mathrm{ppm})$ & 48.53 & 98.63 & 0.33 & 0.38 \\
5. & $\mathrm{Ca}(\mathrm{ppm})$ & 1102.77 & 390.43 & 0.18 & 0.21 \\
6. & $\mathrm{Mg}(\mathrm{ppm})$ & 48.53 & 44.62 & 2.70 & 3.47 \\
7. & $\mathrm{Cu}(\mathrm{ppm})$ & 0.41 & 0.38 & 17.20 & 20.80 \\
8. & $\mathrm{Zn}(\mathrm{ppm})$ & 0.46 & 0.51 & - & - \\
9. & $\mathrm{B}(\mathrm{ppm})$ & 0.22 & 0.31 & & - \\
\hline
\end{tabular}


prevailed in the area, resulting in poor productivity of the main crop coconut rather than intercrops. This result is in tune with the findings of Fageria (2001) that phosphorus uptake by rice plants in nutrient solution was significantly decreased with increasing $\mathrm{Ca}$ concentration and similar is the case with $\mathrm{K}$ and $\mathrm{Mg}$ also, but at a non-significant level. Fageria and Baligar (1999) also reported a decrease in concentrations of $\mathrm{Mg}, \mathrm{Zn}, \mathrm{Mn}$, and $\mathrm{Fe}$ in wheat and soybean plants with increasing $\mathrm{Ca}$ content in the soil. Accordingly, location-specific recommendations were imparted to the farmers for the correction of $\mathrm{Mg}, \mathrm{K}$ and $\mathrm{Cu}$ and $\mathrm{B}$ deficiency. It included a reduction in the lime application, application of $\mathrm{Mg}$ sulphate, borax, copper sulphate and $\mathrm{Zn}$ sulphate.

It was observed that nutrient antagonism between $\mathrm{Ca}$ and $\mathrm{K}$ was reduced evidently due to the soil test based nutrient management. However, no significant improvement in organic matter status was observed owing to the innate textural characteristics of the coastal sandy soil in the experiment tract.

Comparison of leaf nutrient status between pre and post-intervention periods revealed improvements in the levels of $\mathrm{K}, \mathrm{Ca}, \mathrm{Cu}$ and $\mathrm{Zn}$. However, greater differences were not observed in the case of Ca and $\mathrm{Mg}$. Due to greater Ca content in the soil and near-neutral $\mathrm{pH}$, the lime application was discontinued. Crop uptake and further partitioning of these nutrients in different palm components might have resulted in the lesser improvement in these nutrients in the leaves.

\section{Diversification of crops for income enhancement}

Due to the capacity building programmes, farmlevel production of bio-inputs and facilitation in the procurement of planting materials of vegetables, tuber crops, ginger and turmeric and horizontal dissemination to the entire block area through farm schools, improvements were observed in the area under various intercrops as well as income generation (Table 4).

The average area under intercrops increased by 80 per cent and income from intercrops doubled over the project period. Among various intercrops, the area under vegetables and tubers doubled with income enhancements around four-fold and 2.2 fold, respectively. As the farmers of the area generally followed organic vegetable cultivation, the technical support related to bio-resource management enabled the farmers in timely and proper adoption of plant health management techniques, thereby improving the income by four-fold. Similarly, the varietal diversification, timely planting and adoption of proper organic management practices resulted in a two-fold increase in income from tuber crops.

\section{Changes in the levels of knowledge and adoption}

Several capacity development programmes resulted in improvements in the level of knowledge of the beneficiary farmers, which in turn resulted in a higher level of adoption (Table 5).

The average knowledge index of the respondents related to bio-resource management increased by 115.83 per cent, and that of integrated

Table 4. Average area and income under different intercrops and income generation - pre and post interventions

\begin{tabular}{|c|c|c|c|c|c|c|}
\hline \multirow[t]{2}{*}{ Crop } & \multicolumn{3}{|c|}{ Area (acres) } & \multicolumn{3}{|c|}{ Income (₹ ha-1) } \\
\hline & 2014 & 2016 & $\%$ change & 2014 & 2016 & $\%$ change \\
\hline \multirow[t]{2}{*}{ Vegetables } & 8.49 & 20.94 & 146.64 & 13856 & 55759 & 302.41 \\
\hline & & & (2.5 fold) & & & (4 fold) \\
\hline \multirow[t]{2}{*}{ Tubers } & 2.79 & 6.30 & 125.80 & 9933 & 21697 & 118.43 \\
\hline & & & (2.4 fold) & & & (2.2 fold) \\
\hline Banana & 4.74 & 6.66 & 40.51 & 15174 & 27715 & 82.65 \\
\hline Spices & 0.98 & 1.46 & 48.98 & 2705 & 4247 & 57 \\
\hline Arecanut/ fruit crops/ others & 6.18 & 6.36 & 2.91 & 9118 & 13945 & 52.94 \\
\hline Total & 23.18 & 41.72 & 79.98 & 50786 & 123363 & 142.91 \\
\hline
\end{tabular}


Community-level management of bio-resources in coconut farming

Table 5. Improvements in knowledge and adoption levels of the respondents

\begin{tabular}{lcccc}
\hline Particulars & Pre & Post & Change (\%) & $t$ value \\
\hline $\begin{array}{l}\text { Average knowledge index related to bio-resource } \\
\text { management }\end{array}$ & $44.41 \pm 21.68$ & $95.84 \pm 5.33$ & 115.83 & $16.612(\mathrm{P}<0.0001)$ \\
$\begin{array}{l}\text { Average knowledge index related to integrated } \\
\text { nutrient management }\end{array}$ & $54.17 \pm 20.77$ & $94.55 \pm 11.79$ & 74.54 & $12.192(\mathrm{P}<0.0001)$ \\
$\begin{array}{l}\text { Average knowledge index related to coconut } \\
\text { cultivation practices }\end{array}$ & $58.65 \pm 17.85$ & $91.81 \pm 11.39$ & 56.54 & $11.293(\mathrm{P}<0.0001)$ \\
$\begin{array}{l}\text { Average adoption index related to coconut } \\
\text { cultivation practices }\end{array}$ & $40.52 \pm 20.89$ & $83.51 \pm 8.37$ & 106.10 & $13.775(\mathrm{P}<0.0001)$ \\
\hline
\end{tabular}

nutrient management increased by 74.54 per cent. The demonstration farmers, in general, possessed moderately higher knowledge index on coconut cultivation practices with more of awareness rather than correct practical application before initiation of the project (58.65), over which improvement to the tune of 56.54 per cent was observed due to practical trainings under the project. Due to intensive skill development, the adoption of coconut technologies was enhanced by 106 per cent over the pre-project period.

\section{Improvements in setting percentage and yield of coconut}

Coconut being a perennial crop responds slowly to any management practice and as such yield improvements due to increased setting only can be expected within two years. One palm each were selected from all the 52 demonstration gardens for imposing treatments and observations, and the data related to setting and yield improvements in the selected palms and the average improvements in yield from the demonstration gardens, in general, were recorded and provided in Table 6.
An improvement in setting percentage of 32.44 per cent was observed in the observational palms one year after introducing the interventions (during 2015), which was reflected in the yield improvement of 30.64 per cent in the subsequent year (during 2016). Further improvement (45.48\%) was observed in the setting percentage during 2016. The average yield in general from the demonstration gardens also recorded an improvement to the tune of 25.47 per cent over two years.

\section{The economic impact of interventions}

Technology integration with special emphasis to bio-resource management resulted in the income from coconut, intercrops and livestock, thereby leading to enhancement in total farm income (Table 7).

The income from coconut recorded 26 per cent improvement, and that of intercrops by 142.91 per cent and livestock and other enterprises to the tune of 30.88 per cent, contributing to an increase in the average farm income by 149.84 per cent over the project period.

Table 6. Improvements in setting percentage and yield of coconut

\begin{tabular}{|c|c|c|c|c|c|c|}
\hline Attribute & 2014 & 2015 & $\begin{array}{c}\text { Improvement } \\
2014-15(\%)\end{array}$ & 2016 & $\begin{array}{c}\text { Improvement } \\
2014-16(\%)\end{array}$ & $t$ value \\
\hline $\begin{array}{l}\text { Setting percentage in } \\
\text { observational palms }\end{array}$ & $\begin{array}{l}30.67 \pm \\
16.28\end{array}$ & $\begin{array}{l}40.62 \pm \\
18.67\end{array}$ & $\begin{array}{l}32.44 \\
18.71\end{array}$ & $44.62 \pm$ & 45.48 & $\begin{array}{c}4.056 \\
(p<0.0001)\end{array}$ \\
\hline Yield of observational palms & $\begin{array}{l}63.87 \pm \\
39.93\end{array}$ & $\begin{array}{l}69.45 \pm \\
42.01\end{array}$ & $\begin{array}{r}8.74 \\
39.21\end{array}$ & $83.44 \pm$ & 30.64 & $\begin{array}{c}2.522 \\
(\mathrm{P}=0.0132)\end{array}$ \\
\hline $\begin{array}{l}\text { Average yield/palm in } \\
\text { demonstration gardens }\end{array}$ & $\begin{array}{c}28.58 \pm \\
7.13\end{array}$ & $\begin{array}{l}30.02 \pm \\
11.33\end{array}$ & $\begin{array}{r}5.04 \\
15.78\end{array}$ & $35.86 \pm$ & 25.47 & $\begin{array}{c}3.032 \\
(\mathrm{P}=0.0031)\end{array}$ \\
\hline
\end{tabular}


Table 7. Improvements in income generation from coconut based farming systems

\begin{tabular}{lrrr}
\hline Components & \multicolumn{2}{c}{ Net Income $\left(\mathbf{F} \mathbf{h a}^{-\mathbf{1}}\right)$} & $\%$ \\
\cline { 2 - 3 } & $\mathbf{2 0 1 4}$ & $\mathbf{2 0 1 6}$ & change \\
\hline Coconut & 24,475 & 30,853 & 26.06 \\
Intercrops & 50786 & 130320 & 142.91 \\
Livestock/other enterprises & 41,412 & 54,202 & 30.88 \\
\hline Total farm income & $1,16,673$ & $2,91,493$ & 149.84 \\
\hline
\end{tabular}

\section{Conclusion}

The major problems faced by farmers practising organic farming are lack of proper knowledge on the organic inputs to be used and availability of quality organic inputs. Apart from this, the project area, Kanjikuzhy block - having littoral sandy soil characterized by low organic matter content and poor water holding capacity - was found to have several constraints concerning soil fertility status, viz., the chronic shortage of $\mathrm{K}, \mathrm{Mg}$ and $\mathrm{B}$ and a higher level of $\mathrm{Ca}$ and $\mathrm{P}$, most of which linked to over-liming resulting in poor productivity of the main crop coconut rather than intercrops. Awareness creation and adoption of lime and other nutrients based on regular soil testing along with efficient utilization of microbe-enriched organics resulted in increased setting percentage and gradual improvement in the yield of coconut. Farmers could resolve the problem of non-availability of quality organic inputs and constraints related to soil fertility to a greater extent through the utilization of two enriched organic manures from locally available organic substrates and green manure, which encouraged the farmers to bring more area under intercrops and to achieve sustainable income from intercrops, in addition to the generation of supplementary income through the sale of enriched organic manure. Farm-based participatory action management involving experiential learning and adoption, coupled with continuous field-level assessment and refinement was found to strengthen the confidence of the farmers to accept farming as a profitable enterprise.

\section{Acknowledgements}

The authors acknowledge Indian Council of Agricultural Research (ICAR), New Delhi and ICAR-Central Plantation Crops Research Institute for the support provided in carrying out the research project and National Bank for Agriculture and Rural Development (NABARD) for the financial assistance provided for the project.

\section{References}

Alfano, G., Lewis Ivey, M.L., Cakir, C., Bos, J.I.B., Miller, S.A., Madden, L.V., Kamoun, S. and Hoitink, H.A.J. 2007. Systemic modulation of gene expression in tomato by Trichoderma hamatum 382. Phytopathology 97: 429-437.

El-Mohamedy, R.S.R. and Abd-El-Baky, M.M.H. 2008. Effect of seed treatment on control of root rot disease and improvement growth and yield of pea plants. Middle Eastern and Russian Journal of Plant Science and Biotechnology 2(2): 84-90.

Fageria, N.K. and Baligar, V.C. 1999. Growth and nutrient concentrations of common bean, lowland rice, corn, soybean, and wheat at different soil $\mathrm{pH}$ on an Inceptisol. Journal of Plant Nutrition 22: 1495-1507.

Fageria, V.D. 2001. Nutrient interactions in crop plants. Journal of Plant Nutrition 24(8): 1269-1290, DOI: 10.1081/PLN-100106981.

National Research Council. 1989. Alternative Agriculture. Washington, DC: The National Academies Press. Pp.464. https://doi.org/10.17226/1208.

Reddy, V. and Sang-Arun, J. 2011. Promoting coconut-based agro-ecosystem and efficient product utilisation for augmenting on-farm income, improving quality of environment and conserving natural resources. Occasional paper. IGES. 25p.

Shukla, N., Aswathi, R.P., Rawat, L. and Kumar, J. 2014. Seed bio-priming with drought tolerant isolates of Trichoderma harzianum promote growth and drought tolerance in Triticum aestivum. Annals of Applied Biology 166: 171-182.

Subramanian, P., Reddy, D.V.S., Palaniswamy, C., Upadhyay, A.K. and Gopalasundaram, P. 2005. Studies on nutrient export and extent of nutrient recycling in coconut based HDMSCS (High Density Multispecies Cropping System). CORD 21(1): 20-27.

Thomas, G.V. and Shantaram, M.V. 1984. In situ cultivation and incorporation of green manure legumes in coconut basins. Plant and Soil 80: 373-380. 